\title{
The flaxseed lignan secoisolariciresinol diglucoside decreases local inflammation, suppresses NFKB signaling, and inhibits mammary tumor growth
}

\author{
Laura W. Bowers $^{1,2}$ D $\cdot$ Claire G. Lineberger ${ }^{1}$ Nikki A. Ford ${ }^{3} \cdot$ Emily L. Rossi $^{1,2} \cdot$ Arunima Punjala $^{1} \cdot$ Kristina K. Camp $^{1}$. \\ Bruce K. Kimler ${ }^{4}$ Carol J. Fabian ${ }^{5}$ Stephen D. Hursting ${ }^{1,2,6}$
}

Received: 3 August 2018 / Accepted: 20 October 2018 / Published online: 26 October 2018

(c) The Author(s) 2018

\begin{abstract}
Purpose Exposure to the polyphenolic plant lignan secoisolariciresinol diglucoside (SDG) and its metabolite enterolactone (ENL) has been associated with reduced breast cancer progression, particularly for estrogen receptor alpha (ER $\alpha)$-negative disease, and decreased preclinical mammary tumor growth. However, while preclinical studies have established that SDG and ENL affect measures of progression in models of triple-negative breast cancer (TNBC, a subset of ER $\alpha$-negative disease), the molecular mechanisms underlying these effects remain unclear.

Methods C57BL/6 mice were fed a control diet (control, $10 \% \mathrm{kcal}$ from fat) or control diet + SDG (SDG, $100 \mathrm{mg} / \mathrm{kg} \mathrm{diet)} \mathrm{for}$ 8 weeks, then orthotopically injected with syngeneic E0771 mammary tumor cells (a model of TNBC); tumor growth was monitored for 3 weeks. The role of reduced NF- $\kappa$ B signaling in SDG's anti-tumor effects was explored in vitro via treatment with the bioactive SDG metabolite ENL. In addition to the murine E0771 cells, the in vitro studies utilized MDA-MB-231 and MCF-7 cells, two human cell lines which model the triple-negative and luminal A breast cancer subtypes, respectively. Results SDG supplementation in the mice significantly reduced tumor volume and expression of phospho-p65 and NF- $\mathrm{B}$ target genes $(P<0.05)$. Markers of macrophage infiltration were decreased in the distal-to-tumor mammary fat pad of mice supplemented with SDG relative to control mice $(P<0.05)$. In vitro, ENL treatment inhibited viability, survival, and NF- $\kappa B$ activity and target gene expression in E0771, MDA-MB-231, and MCF-7 cells $(P<0.05)$. Overexpression of Rela attenuated ENL's inhibition of E0771 cell viability and survival.

Conclusions SDG reduces tumor growth in the E0771 model of TNBC, likely via a mechanism involving inhibition of NF- $\mathrm{kB}$ activity. SDG could serve as a practical and effective adjuvant treatment to reduce recurrence, but greater understanding of its effects is needed to inform the development of more targeted recommendations for its use.
\end{abstract}

Keywords Breast cancer $\cdot$ Secoisolariciresinol diglucoside $($ SDG) $\cdot$ Plant lignan $\cdot$ Enterolactone $($ ENL) $\cdot$ Enterodiol $(\mathrm{END}) \cdot \mathrm{NF} \kappa \mathrm{B}$

Electronic supplementary material The online version of this article (https://doi.org/10.1007/s10549-018-5021-6) contains supplementary material, which is available to authorized users.

Stephen D. Hursting hursting@email.unc.edu

1 Department of Nutrition, University of North Carolina, 135 Dauer Drive, CB \#7461, Chapel Hill, NC 27599, USA

2 Lineberger Comprehensive Cancer Center, University of North Carolina, 450 West Drive, Chapel Hill, NC 27514, USA

3 Department of Nutritional Sciences, University of Texas at Austin, 1400 Barbara Jordan Blvd, R1800, Austin, TX 78723, USA

\section{Abbreviations \\ ANOVA Analysis of variance \\ CLS Crown-like structure}

4 Department of Radiation Oncology, University of Kansas Medical Center, 3901 Rainbow Boulevard, Kansas City, KS 66160, USA

5 Department of Internal Medicine, University of Kansas Medical Center, 3901 Rainbow Boulevard, Kansas City, KS 66160, USA

6 Nutrition Research Institute, University of North Carolina, 500 Laureate Way, Kannapolis, NC 28081, USA 


$\begin{array}{ll}\text { END } & \text { Enterodiol } \\ \text { ENL } & \text { Enterolactone } \\ \text { ER } \alpha & \text { Estrogen receptor alpha } \\ \text { GM-CSF } & \begin{array}{l}\text { Granulocyte-macrophage colony-stimulating } \\ \text { factor }\end{array} \\ \text { IFN- } \gamma & \text { Interferon gamma } \\ \text { IL-1 } \beta & \text { Interleukin 1 beta } \\ \text { IL-6 } & \text { Interleukin 6 } \\ \text { IL-10 } & \text { Interleukin 10 } \\ \text { LPS } & \text { Lipopolysaccharide } \\ \text { MCP-1 } & \text { Macrophage chemoattractant protein 1 } \\ \text { NC } & \text { Negative control vector } \\ \text { NF- }- \text { B } & \text { Nuclear factor-kappa B } \\ \text { SD } & \text { Standard deviation } \\ \text { SDG } & \text { Secoisolariciresinol diglucoside } \\ \text { SEM } & \text { Standard error of the mean } \\ \text { STAT3 } & \text { Signal transducer and activator of transcription } \\ & 3 \\ \text { TNBC } & \text { Triple-negative breast cancer } \\ \text { TNF- } \alpha & \text { Tumor necrosis factor alpha }\end{array}$

\section{Background}

Secoisolariciresinol diglucoside (SDG) is a polyphenolic plant lignan found in flaxseeds and other oil-rich seeds and nuts as well as legumes, whole grains, certain fruits and vegetables, coffee, tea, and wine [1, 2]. Following oral consumption, SDG is hydrolyzed to secoisolariciresinol and then metabolized by intestinal bacteria to two biologically active enterolignans that have been classified as phytoestrogens: enterolactone (ENL) and enterodiol (END) [3]. Studies have generally found significant inverse associations between lignan exposure and breast cancer mortality [4-8]. However, only one study included premenopausal women [6] and another found that effects were limited to estrogen receptor alpha (ER $\alpha)$-negative tumors [4]. Consequently, it is uncertain whether all breast cancer patients would benefit from greater SDG intake post-diagnosis.

To further explore SDG's impact on breast cancer, several preclinical studies have examined the effects of lignan exposure on animal models of both pre- and postmenopausal ER $\alpha$-positive breast cancer, with the vast majority demonstrating significant reductions in mammary tumor growth or preneoplastic changes [9-18]. These anti-tumor effects have been linked to decreased proliferation and angiogenesis as well as increased apoptosis [9-11, 13, 15-17]. However, only a small number of studies have investigated the possible molecular pathways underlying the anticancer effects of SDG [10, 19-21]. In addition, there has been relatively little exploration of SDG's effects on models of triple-negative breast cancer (TNBC), despite epidemiologic data suggesting enterolignans may have a stronger protective effect against mortality from ER $\alpha$-negative tumors [4]. Researchers have demonstrated that SDG metabolites reduce proliferation, adhesion, migration, and invasion in the triplenegative MDA-MB-231 breast cancer cell line and increase these cells' response to radiation and chemotherapy [22-25], but the molecular pathways responsible for these effects have not been established.

The current study examined the impact of SDG supplementation on in vivo growth of orthotopically injected E0771 mouse mammary tumor cells, a syngeneic model of basal-like TNBC [21, 26]. After demonstrating that SDG inhibits E0771 tumor growth in association with decreased tumor activity of the inflammation-regulating transcription factor nuclear factor-kappa B (NF- $\mathrm{KB}$ ), we explored connections between these factors using in vitro models of multiple breast cancer subtypes. Greater understanding of SDG's effects on different breast cancer models and the mechanisms mediating these effects will inform the development of more targeted recommendations regarding the use of SDG supplementation for reducing the burden of breast cancer.

\section{Methods}

\section{In vivo dose-finding pilot study}

Animal studies and procedures were approved and monitored by the University of Texas Institutional Animal Care and Use Committee. Female, 10-week-old C57BL/6 mice were purchased from Charles River Laboratories, Inc., and fed a control diet $(10 \% \mathrm{kcal}$ from fat, catalog \#D12450J, Research Diets, Inc.) ad libitum for 8 weeks. Mice were then randomized to the control diet $(n=10)$ or 1 of 2 control + SDG diets (low-dose SDG: $25 \mathrm{mg} / \mathrm{kg}$ diet, $n=10$; high-dose SDG: $74 \mathrm{mg} / \mathrm{kg}$ diet, $n=10$ ) for 8 weeks. The goal of this study was to establish the concentration of SDG that would result in serum ENL and END levels comparable to those achieved in a 12-month pilot clinical trial of SDG supplementation in women [27]. SDG for both in vivo studies was obtained from Barleans Organic Oils, LLC (Ferndale, WA, USA). Following euthanization, blood was collected by cardiac puncture and serum stored at $-80{ }^{\circ} \mathrm{C}$. The 4 th mammary gland was excised, flash-frozen in liquid nitrogen and stored at $-80{ }^{\circ} \mathrm{C}$.

\section{In vivo tumor study}

Animal studies and procedures were approved and monitored by the University of North Carolina Institutional Animal Care and Use Committee. Female, 12-week-old C57BL/6 mice were purchased from Charles River Laboratories, Inc., and fed the control diet ad libitum for 2 weeks. Mice were then randomized to the control diet $(n=20)$ or 
control + SDG diet (100 mg SDG/kg diet, $n=20)$. This dose was chosen because the serum ENL and END levels in the high-dose ( $74 \mathrm{mg} / \mathrm{kg}$ diet) pilot group were $~ 25 \%$ lower than in the clinical trial subjects [27]. After 7 weeks, blood was collected from all mice by submandibular bleed, and serum stored at $-80{ }^{\circ} \mathrm{C}$. One week later, all mice were orthotopically injected with $3.5 \times 10^{4}$ syngeneic E0771 mammary tumor cells. In vivo tumor growth was measured twice/ week with digital calipers, and all mice euthanized 3 weeks after injection. Mice remained on their respective control or control + SDG diets throughout the study. Tumors and the 4th and 9th mammary glands were excised and divided to be formalin fixed and paraffin-embedded or flash-frozen in liquid nitrogen and stored at $-80^{\circ} \mathrm{C}$. The ellipsoid equation was used to determine volume ex vivo: $1 / 6 \pi(\mathrm{D} 1 \times \mathrm{D} 2 \times \mathrm{D} 3)$. Body fat was assessed after euthanization using a Lunar PIXImus Dual Emission X-Ray Absorptiometer (GE Medical Systems, Ontario, CA).

\section{Serum enterolactone and cytokine measurement}

To measure serum ENL and END concentrations, samples underwent solid-phase extraction and overnight enzymatic hydrolysis. The unconjugated lignans were then isolated by solid-phase extraction, converted to tert-butyldimethylsilyl ethers, and analyzed by gas chromatography mass spectrometry [28]. Serum cytokines were analyzed by Bio-Plex Multiplex Immunoassay on a Bio-Plex ${ }^{\circledR}$ Magpix Multiplex Reader (Bio-Rad, Inc., Hercules, CA, USA).

\section{Quantitative RT-PCR analyses}

Total RNA isolated from tissues and cell culture samples was reverse transcribed and samples assayed in triplicate for individual genes as previously described [29]. Tumor expression of NF- $\mathrm{KB}$ target genes was assessed using a Mouse NF- $\kappa B$ Signaling Target RT ${ }^{2}$ Profiler PCR Array (Qiagen, Germantown, MD, USA). All quantitative RTPCR assays were analyzed using a ViiA ${ }^{\text {TM}} 7$ RT-PCR System (Applied Biosystems, Waltham, MA, USA).

\section{Crown-like structure analysis}

Paraffin-embedded distal-to-tumor mammary gland tissue ( $n=6 /$ group) was cut into $4-\mu \mathrm{m}$-thick sections and stained with hematoxylin and eosin. The total number of crownlike structures (CLS) per section was quantified, and the mammary tissue area determined using Aperio ImageScope (Leica Biosystems, Buffalo Grove, IL, USA). Prevalence of CLS was quantified as CLS per $\mathrm{cm}^{2}$ of mammary tissue.

\section{Immunohistochemical analyses}

Paraffin-embedded tumor tissue ( $n=6 /$ group) was cut into $4-\mu \mathrm{m}$-thick sections and stained, processed and analyzed as previously described [30] with the following primary antibodies: F4/80 (Abcam \#ab6640), phospho (p)-p65 (Ser276) (Santa Cruz \#sc-101749), and p-STAT3 (Tyr705) (Cell Signaling \#9131).

\section{Cell lines and reagents}

One mouse mammary tumor cell line, E0771, and two human breast cancer cell lines, MDA-MB-231 and MCF7 , were used for the in vitro studies. All cell lines were maintained in RPMI 1640 media (GIBCO Life Technologies, Grand Island, NY, USA) supplemented with $10 \%$ fetal bovine serum, $10 \mathrm{mM}$ HEPES buffer, and $2 \mathrm{mM}$-glutamine (complete media). ENL was purchased from Sigma-Aldrich (St. Louis, MO, USA) and dissolved in ethanol. Two ENL concentrations, $1 \mu \mathrm{M}$ and $10 \mu \mathrm{M}$, were chosen based on the literature $[22,31,32]$ and utilized for all in vitro experiments.

\section{In vitro cell viability and survival assays}

For the cell viability assay, cells were seeded at a density of $5 \times 10^{3}$ in 96-well plates. After $24 \mathrm{~h}$, the cells were treated with vehicle, $1 \mu \mathrm{M}$ or $10 \mu \mathrm{M}$ ENL in complete media for $48 \mathrm{~h}$. MTT reagent was used to assess cell viability levels as previously described $[33,34]$. For the cell survival assay, cells were seeded at a density of $1 \times 10^{3}$ in 6 -well plates. After $24 \mathrm{~h}$, the cells were continuously exposed to vehicle, $1 \mu \mathrm{M}$ or $10 \mu \mathrm{M}$ ENL in complete media for 7 days, with the treatments replenished on day 4 . The colonies were fixed and stained with $0.5 \%$ crystal violet in $50 \%$ methanol, counted, and imaged with a digital camera on day 7 .

\section{In vitro NF-KB activity}

The impact of ENL on NF- $\mathrm{BB}$ activity was assessed via a NF-KB Cignal Reporter Assay (Qiagen) and quantitative RT-PCR for NF- $\mathrm{kB}$ target gene expression. For the NF- $\mathrm{KB}$ Reporter Assay, cells were seeded at a density of $2.5 \times 10^{3}$ in 96-well plates. After $24 \mathrm{~h}$, the cells were transfected with the NF- $\kappa B$ Reporter mixture (an inducible NF- $\kappa B$-responsive firefly luciferase reporter + a constitutively expressing Renilla construct) using FuGENE ${ }^{\circledR} 6$ (Promega, Madison, WI, USA). After another 24-h incubation, cells were treated with vehicle, $1 \mu \mathrm{M}$ or $10 \mu \mathrm{M}$ ENL in complete media for $48 \mathrm{~h}$, followed by the same treatments plus LPS $(10 \mathrm{ng} / \mathrm{ml})$ in complete media for $24 \mathrm{~h}$. The cells' luciferase activity was measured using Promega's Dual Luciferase ${ }^{\circledR}$ Reporter Assay System on a Cytation 3 Cell Imaging Multi-Mode Reader 
(BioTek Instruments Inc.). For NF- $\mathrm{B}$ target gene measurement, cells were seeded at a density of $1.5 \times 10^{5}$ in 6 -well plates. After $24 \mathrm{~h}$, cells were treated with vehicle, $1 \mu \mathrm{M}$ or $10 \mu \mathrm{M}$ ENL in complete media for $48 \mathrm{~h}$, followed by the same treatments plus LPS $(10 \mathrm{ng} / \mathrm{ml})$ in complete media for $24 \mathrm{~h}$. Four NF- $\kappa \mathrm{B}$ target genes were chosen to assess in vitro from the 41 target genes with significantly lower expression in SDG mice versus controls; criteria for inclusion were a known link to breast cancer progression and $P<0.01$ for the in vivo $\mathrm{NF}-\kappa \mathrm{B}$ target gene array.

\section{Rela overexpression}

The Mouse pCMV3-GFPSpark-mRela Plasmid (Rela; a Rela overexpression plasmid) and the pCMV3-N-GFPSpark Control Vector (NC), purchased from Sino Biological, Inc. (Beijing, China), were transiently transfected into E0771 cells using FuGENE ${ }^{\circledR} 6$ (Promega). Nuclear p65 expression was measured $48 \mathrm{~h}$ after transfection by western blot analysis using NF- $\kappa$ B p65 (D14E12) XP ${ }^{\circledR}$ Rabbit antibody (Cell Signaling \#8242). E0771 cells were seeded for the MTT and colony formation assays $48 \mathrm{~h}$ after transfection with the Rela and NC plasmids. The assays then proceeded as described above.

\section{Statistical analyses}

Animal study data are presented as mean $\pm \mathrm{SD}$ and in vitro data as mean \pm SEM. All in vitro data shown represent the average of at least 3 independent experiments. For all statistical tests, GraphPad Prism software was used (GraphPad Software Inc., La Jolla, CA, USA). Differences between animals or cells exposed to 2 experimental conditions were analyzed using Student's $t$ test. Differences between cells exposed to more than 2 experimental conditions were analyzed using one-way ANOVA (1 independent variable) or two-way ANOVA ( $>1$ independent variable), both followed by Tukey's post hoc test. $P<0.05$ was considered significantly different.

\section{Results}

\section{High-dose SDG supplementation increases serum ENL and END levels}

We first performed a pilot animal study to determine the SDG concentration in murine diet that achieves ENL and END levels comparable to those in women that received $50 \mathrm{mg} /$ day of SDG for 12 months in a pilot clinical trial [27]. C57BL/6 mice fed the high-dose diet ( $74 \mathrm{mg} / \mathrm{kg} \mathrm{SDG})$ had significantly greater serum ENL and END levels in comparison with mice fed the control diet $(P<0.05$ for both)
(Fig. 1a, b), though these levels were approximately $25 \%$ lower than those achieved in the pilot clinical trial [27]. In addition, mammary tissue gene expression of the pro-inflammatory chemokine $C c l 2$ was reduced in mice fed the highdose SDG diet versus control mice $(P<0.001)$ (Fig. 1c). No significant differences were observed in expression of $I l 6$ or $\operatorname{Tnf}$ (data not shown).

\section{SDG supplementation reduces mammary inflammation}

No differences were observed in the in vivo tumor study in body weight throughout the 11-week study period or body
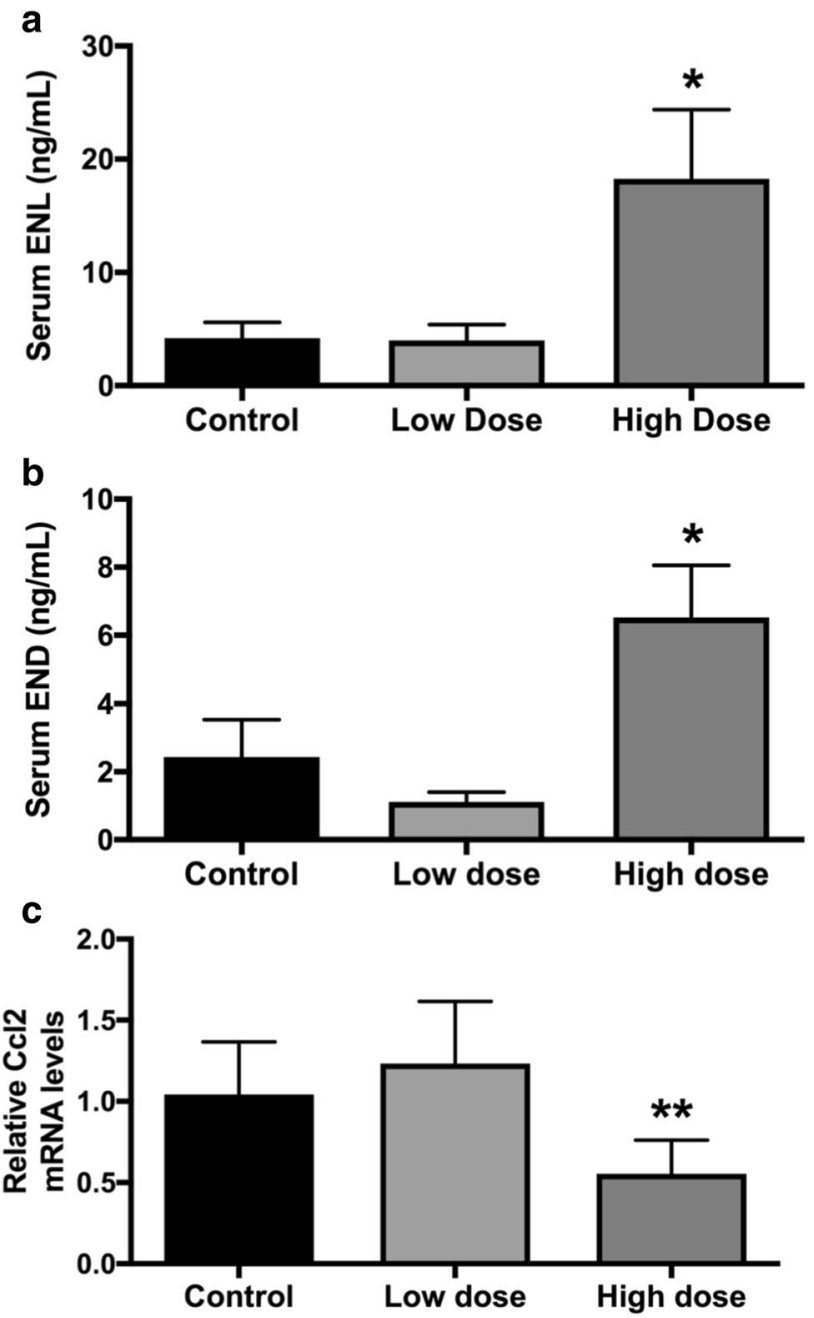

Fig. 1 Serum ENL and END levels are increased in mice receiving high-dose SDG. Serum ENL (a) and END (b) levels were measured in mice receiving a control diet, low-dose SDG-supplemented diet (low dose; $25 \mathrm{mg} / \mathrm{kg}$ diet), or high-dose SDG-supplemented diet (high dose; $74 \mathrm{mg} / \mathrm{kg}$ diet). c $C c l 2$ gene expression in the 4th mammary gland of control, low-dose, and high-dose mice was measured by quantitative RT-PCR. ${ }^{*} P<0.05 ; * * P<0.01$ in comparison with control 
fat percentage at study termination between control mice versus SDG-supplemented mice (Fig. 2a, b). Given that our pilot study suggested that SDG may have anti-inflammatory effects in the mammary tissue, we next examined whether SDG affected inflammatory markers in the nontumor-bearing mammary gland. Expression of Adgrel (the gene for F4/80) and the prevalence of crown-like structures (CLS) were both significantly reduced in the mammary gland of SDG-supplemented mice relative to control mice $(P<0.05$ for both) (Fig. 2c, d). We also examined SDG's effects on systemic inflammation by measuring serum levels of 7 inflammatory cytokines (IL-1 $\beta$, IL-6, IL-10, GM-CSF,
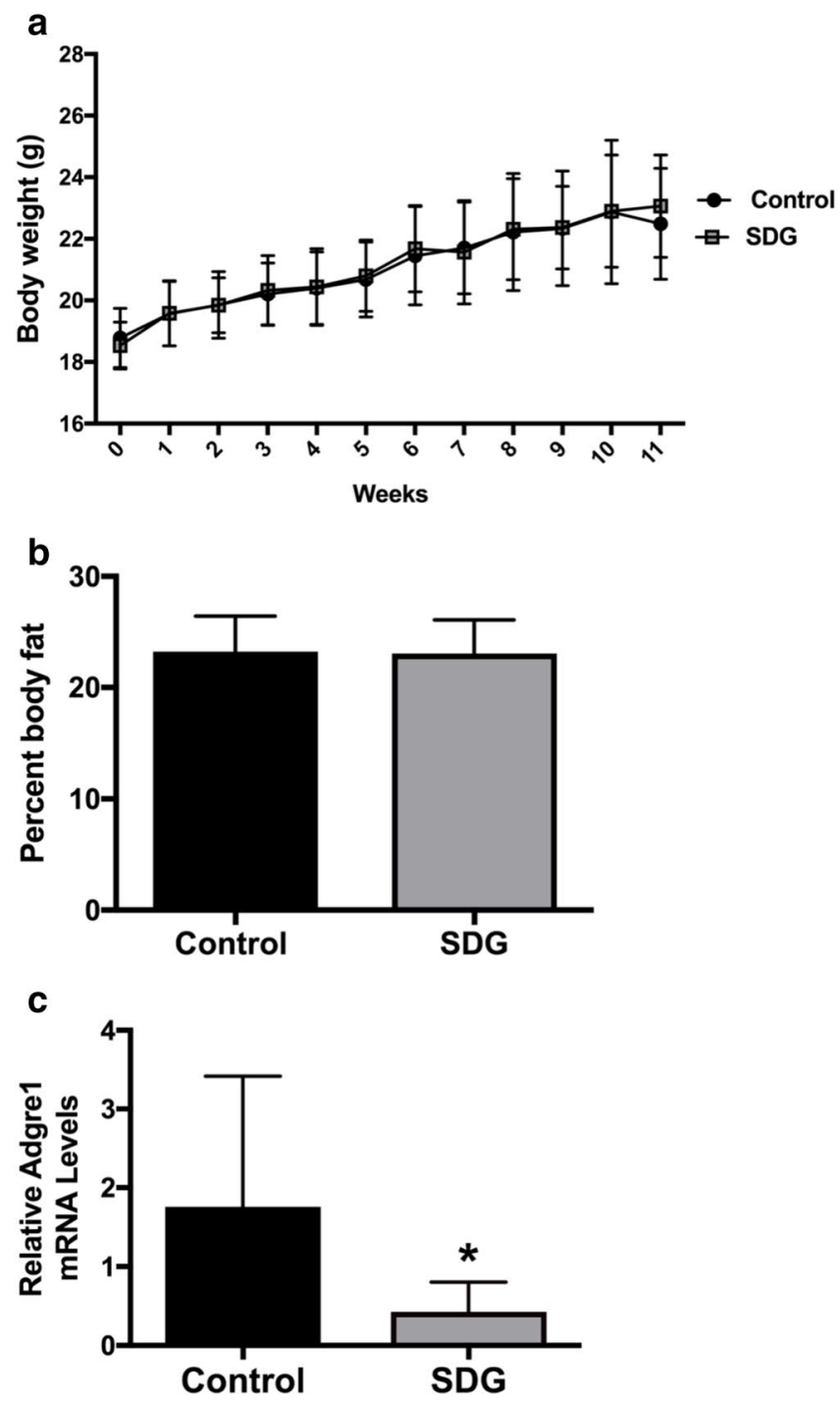

Fig. 2 SDG supplementation reduces mammary inflammation. a Body weights were measured each week in all mice; mean $( \pm \mathrm{SD})$ weekly body weights for the mice maintained on the control or SDG-supplemented (SDG) diets are shown. b Final percent body fat levels in mice fed the control and SDG diets were measured following euthanization. c Adgre1 expression in the 9th (tumor-distal) mammary gland was measured by quantitative RT-PCR in control
IFN- $\gamma$, MCP-1, and TNF- $\alpha$ ), but found no differences between groups (Online Resource 1).

\section{SDG inhibits mammary tumor growth and NF-KB activity}

Final tumor volume was significantly smaller in the mice receiving $\mathrm{SDG}$ compared with control mice $(P<0.05)$ (Fig. 3a). Tumor mRNA levels of Adgrel were also lower in SDG-supplemented versus control mice $(P<0.05)$ (Fig. 3b). However, F4/80 protein expression was not significantly lower in the tumors from SDG-supplemented mice relative
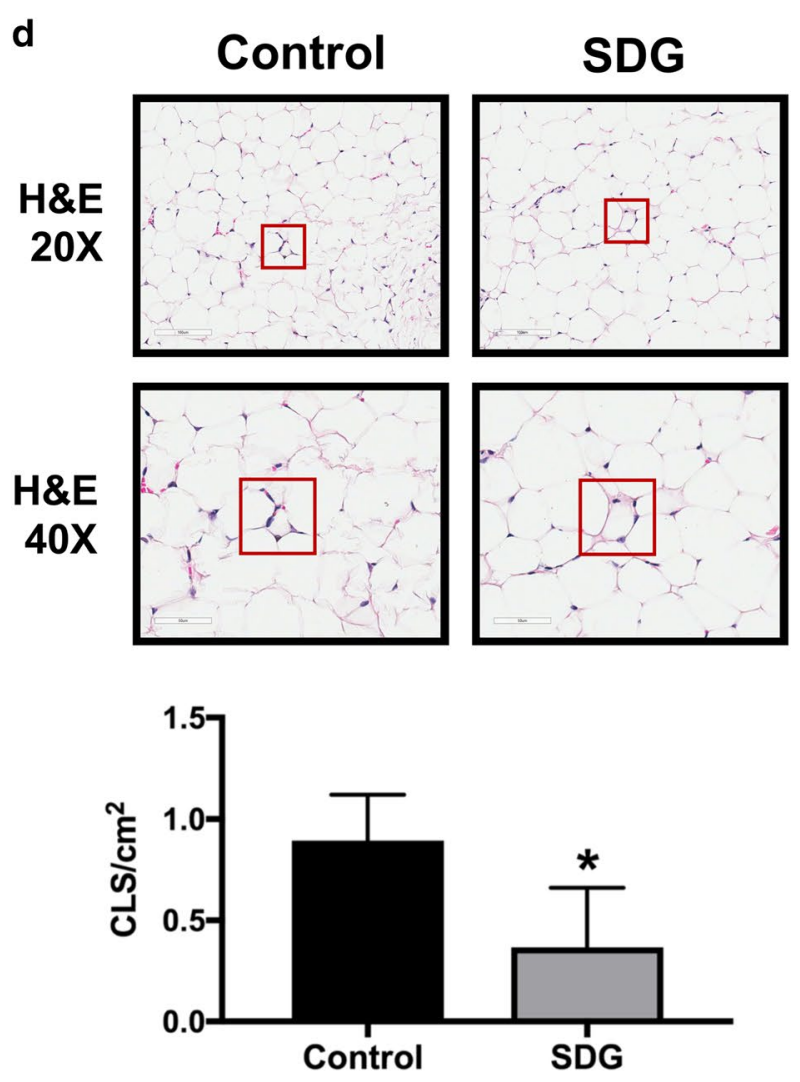

and SDG-supplemented mice. d Prevalence of crown-like structures (CLS) was assessed in the 9th mammary gland of control and SDGsupplemented mice using hematoxylin and eosin (H\&E)-stained tissue sections. Representative images shown at $\times 20$ and $\times 40$ magnification. CLS were quantified for each tissue sample as number of CLS per $\mathrm{cm}^{2} . * P<0.05$ 
a

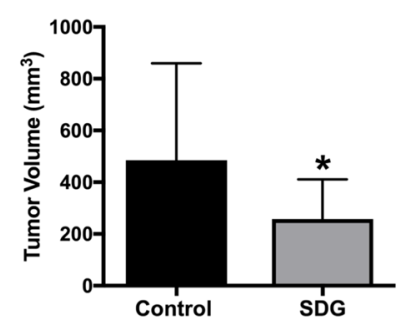

b

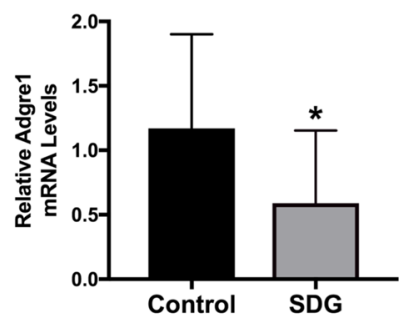

C

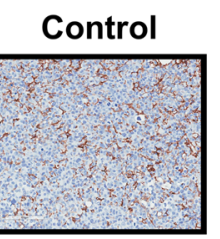

F4/80

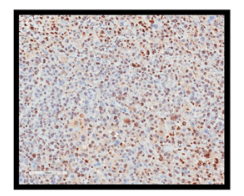

p-p65

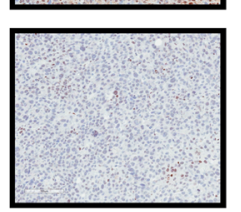

SDG
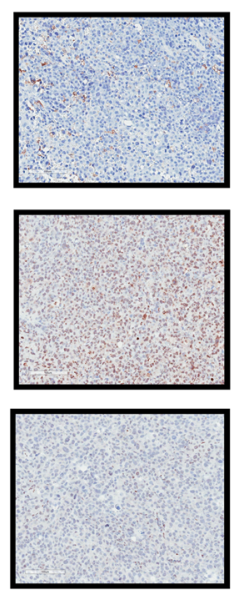

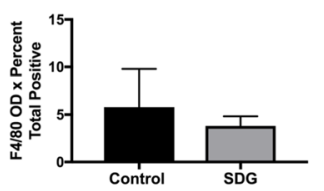

d

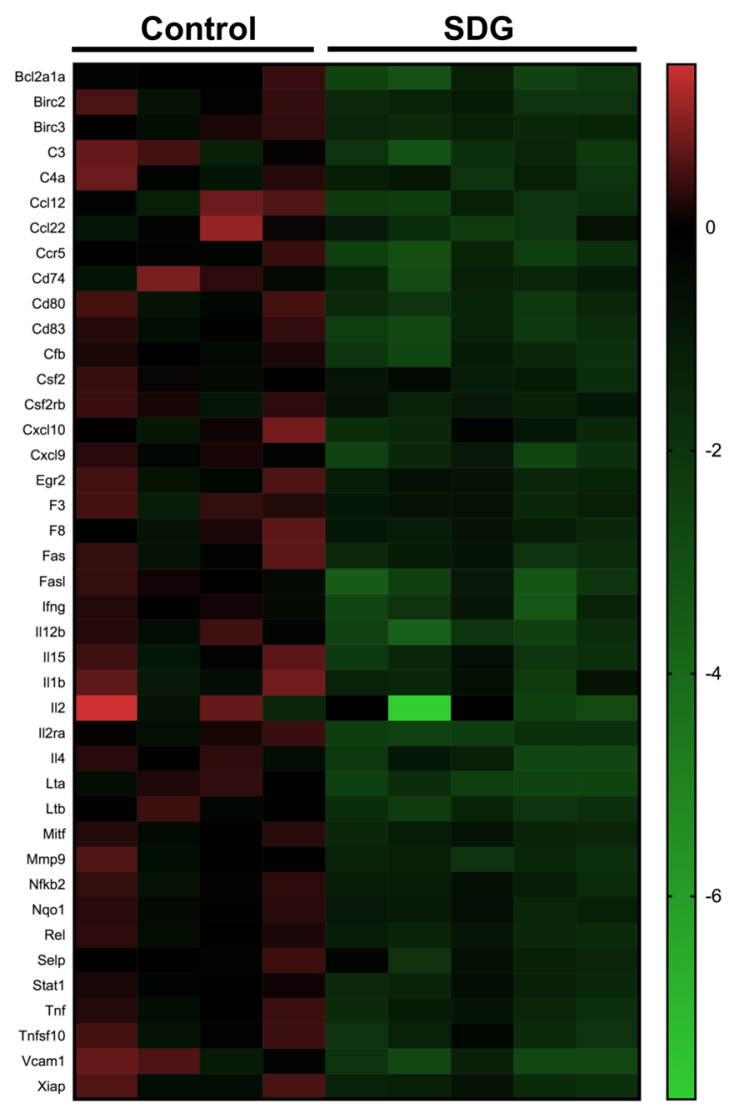

Fig. 3 E0771 mammary tumor growth and NF-kB activity are inhibited by SDG supplementation. a Final tumor volume in mice fed the control or SDG-supplemented (SDG) diets was measured at necropsy. b Tumor Adgre1 expression was measured by quantitative RT-PCR in control and SDG-supplemented mice. c Immunohistochemical staining for tumor F4/80, p-p65 (Ser276), and p-STAT3 (Tyr705) expression in control and SDG-supplemented mice. Representative images shown at $\mathrm{x} 20$ magnification. $\mathbf{d}$ NF- $\mathrm{\kappa B}$ target gene expression in tumors from control and SDG-supplemented mice was assessed using a Mouse NF- $\kappa B$ Signaling Target PCR Array; relative expression of genes that were significantly downregulated $(P<0.05)$ by at least 50\% in SDG-supplemented mice compared with control mice is displayed in the heat map. $* P<0.05$ to controls (Fig. 3c). We then assessed the activation of two pathways that mediate the effects of several inflammatory signaling molecules. Tumor expression of p-p65 (Ser276), the activated form of a subunit of the pro-inflammatory transcription factor $\mathrm{NFKB}$, was significantly lower in SDG-supplemented mice compared with controls $(P<0.05)$. In contrast, tumor expression of p-STAT3 (Tyr705) did not differ between SDGsupplemented and control mice (Fig. 3c). We then utilized a Mouse NF- $\kappa B$ Signaling Target PCR Array to examine the impact of SDG on tumor NFkB target gene expression. Out of 84 genes analyzed, the expression of 41 genes was significantly downregulated by at least $50 \%$ in SDG-supplemented mice compared with controls $(P<0.05)$, while no genes were significantly upregulated (Fig. 3d).

\section{ENL decreases breast cancer cell viability and survival in vitro}

To further explore the mechanisms underlying the anticancer effects of SDG, we utilized 3 mammary tumor cell lines, including the same triple-negative E0771 mouse mammary tumor cells used in the tumor study. In addition, a human TNBC cell line, MDA-MB-231, was used to establish whether results seen in the E0771 cells extend to other TNBC cells. Finally, human MCF-7 cells, which model the ER $\alpha$-positive luminal A subtype of human breast cancer, were used to examine whether any identified mechanisms also mediate ENL's effects on this disease subtype. Both $1 \mu \mathrm{M}$ and $10 \mu \mathrm{M}$ doses of ENL, in comparison with vehicle, 


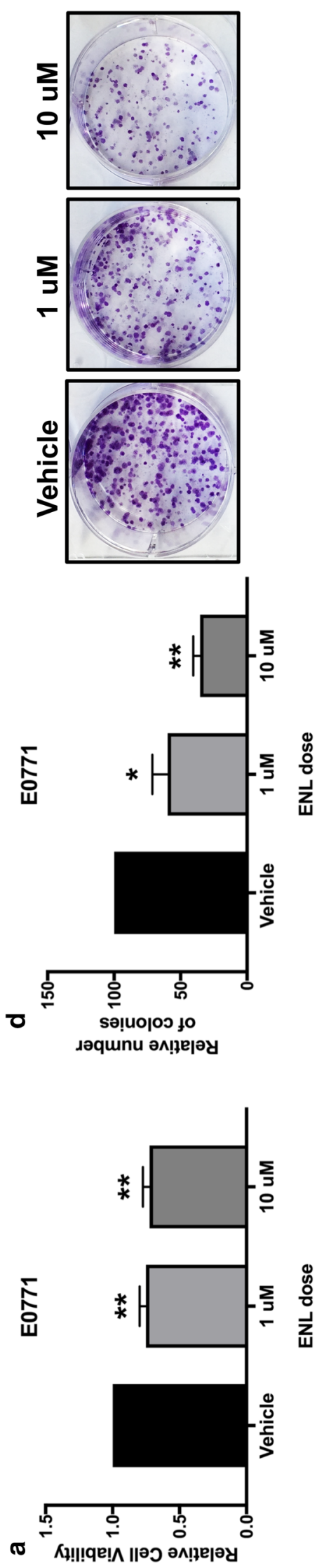

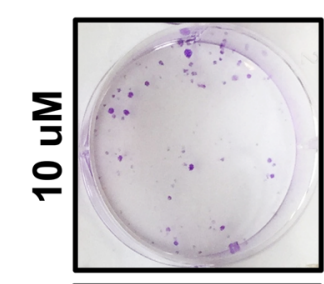
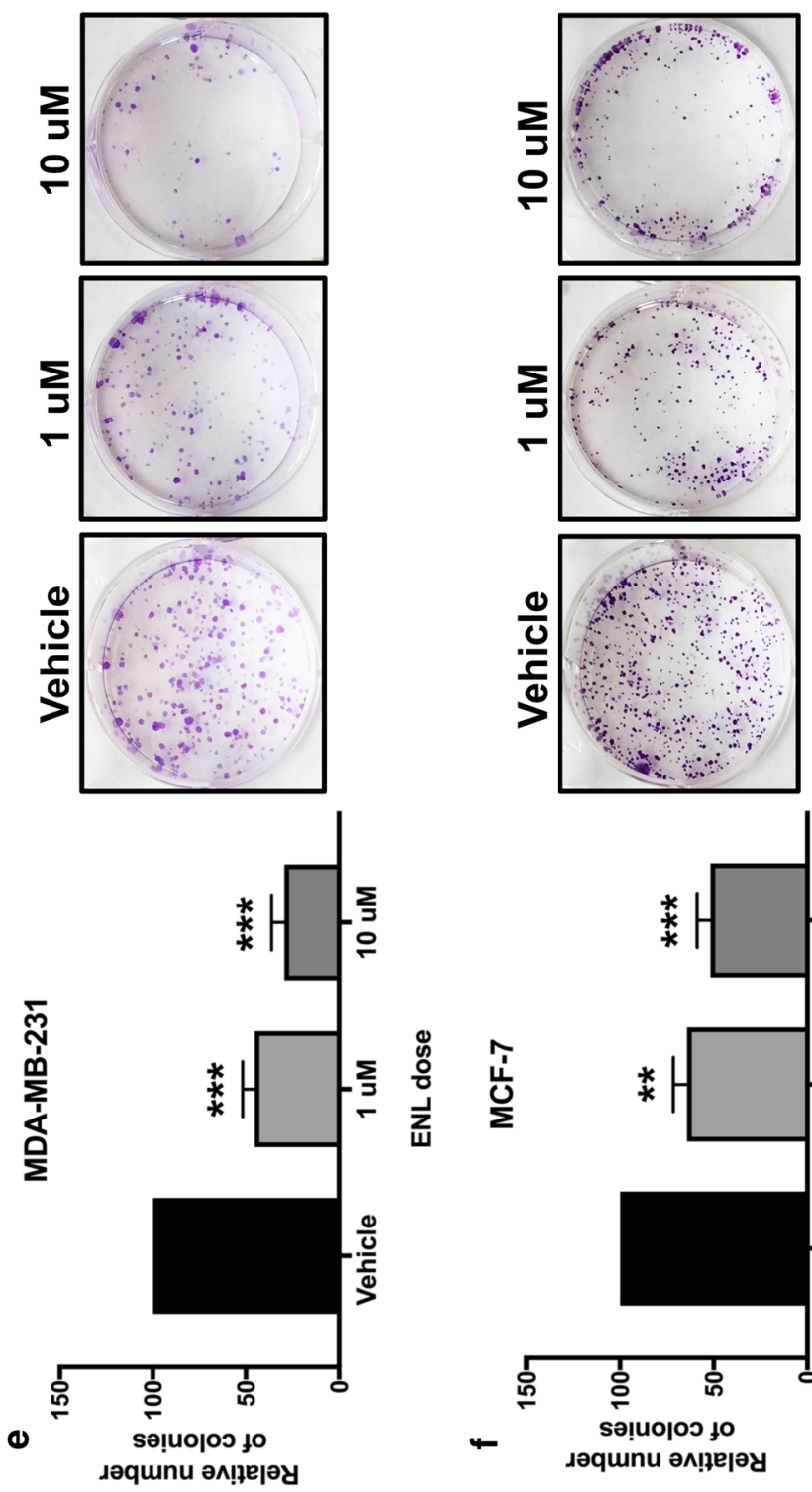

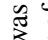

之

正

$\sum_{3}$

은

ᄒ

$\sum_{3}$

曹

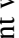

离

可

定

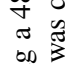

일

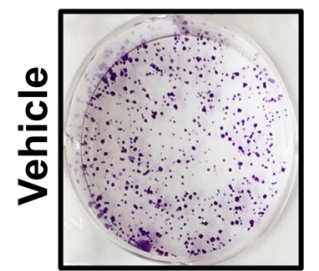

응

링

त्व

$=$

它氞

ปี

ये

롱

ले

ำ

$\sum 0 *$

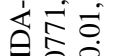

$\sum$ 이 V

- 2

F。 * *

ㅇํㄹ

핑

i $\sum_{2}$

诖 응

它

可

焉二

氖

$0 \%$

ส

을 己

ฮ

컹

:

\%

क ज क

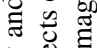

궝

:

零

च

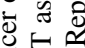

㫐它

范合苛

ज़

ㅎํㄴ 
significantly decreased cell viability in the E0771 $(P<0.01$ for both), MDA-MB-231 (1 $\mu \mathrm{M}, P<0.05 ; 10 \mu \mathrm{M}, P<0.01)$, and MCF-7 $(P<0.001$ for both) cell lines (Fig. $4 \mathrm{a}-\mathrm{c})$. Cell survival was also significantly decreased, relative to vehicle, by both $1 \mu \mathrm{M}$ and $10 \mu \mathrm{M}$ ENL in E0771 $(1 \mu \mathrm{M}, P<0.05$; $10 \mu \mathrm{M}, P<0.01)$, MDA-MB-231 $(P<0.001$ for both $)$ and MCF-7 $(1 \mu \mathrm{M}, P<0.01 ; 10 \mu \mathrm{M}, P<0.001)$ cells (Fig. 4d-f).

\section{ENL inhibits breast cancer cell NF-KB activity}

We next examined the impact of ENL on NF- $\mathrm{KB}$ activity in the 3 mammary tumor cell lines. Both doses of ENL, in comparison with vehicle, significantly decreased relative luciferase activity in E0771 $(P<0.001$ for both), MDAMB-231 ( $P<0.05$ for both), and MCF-7 ( $P<0.01$ for both) cells transfected with an NF- $\mathrm{KB}$ reporter (Fig. 5a-c). We then assessed the effects of ENL treatment on 4 NF- $\mathrm{\kappa B}$ target genes: Csf2, Fasl, Mmp9, and Tnf. In E0771 and MDAMB-231 cells, the expression of $C s f 2, M m p 9$, and $\operatorname{Tnf}$ was significantly decreased by both ENL doses $(P<0.001$ for all $)$ (Fig. 5d, e). In MCF-7 cells, the expression of Mmp 9 was reduced by $10 \mu \mathrm{M}$ ENL $(P<0.05)$, while Tnf expression was decreased by both ENL doses ( $P<0.001$ for both) (Fig. 5f). Fasl expression was not significantly affected by ENL treatment in E0771 or MDA-MB-231 cells (data not shown), and Csf 2 and Fasl expression was not detectable in MCF-7 cells. Finally, we found that NF- $\kappa B$ activity in MCF-7 cells was approximately 100 -fold and 50-fold lower compared with E0771 cells $(P<0.001)$ and MDA-MB-231 cells $(P<0.05)$, respectively, when measured by dual luciferase assay under vehicle control conditions (Fig. 5g).

\section{ENL-induced decreases in E0771 cell viability and survival are mediated by inhibition of NF-KB activity}

To determine whether the observed decrease in cell viability and survival following ENL treatment is mediated by an inhibition of NF-kB activity, we transiently transfected E0771 cells with a Rela overexpression plasmid (Rela) to induce constitutive overexpression of p65. In comparison with E0771 cells transfected with a negative control vector $(\mathrm{NC})$, nuclear p65 expression was significantly increased $(P<0.05)$ in cells transfected with the Rela plasmid (Fig. 6a). Cell viability and survival were then measured in NC and Rela E0771 cells treated with ENL. In NC cells, both doses of ENL promoted a significant decrease in viability $(1 \mu \mathrm{M}, P<0.05 ; 10 \mu \mathrm{M}, P<0.001)$, while ENL did not significantly affect the viability of Rela cells (Fig. 6b). Rela overexpression also prevented ENL's effects on E0771 cell survival, as both $1 \mu \mathrm{M}(P<0.01)$ and $10 \mu \mathrm{M}(P<0.0001)$ doses significantly reduced the relative number of colonies formed by NC cells, but not Rela cells (Fig. 6c).

\section{Discussion}

While the anti-tumor effects of the flaxseed lignan SDG have been thoroughly established in several models of ER $\alpha$-positive breast cancer [9-12, 14-17, 35], less attention has been given to its impact on ER $\alpha$-negative models, including models of basal-like and other triple-negative breast cancer subtypes, and the precise mechanisms mediating their effects. Our findings suggest that SDG may inhibit basal-like breast tumor progression via modulation of NF- $\kappa B$ activity. We specifically report that: (a) SDG supplementation in a mouse model of premenopausal basal-like breast cancer reduces tumor growth and NF- $\kappa \mathrm{B}$ activity; (b) in vitro treatment with ENL, the primary bioactive metabolite of SDG, inhibits cell viability, survival, and NF- $\kappa \mathrm{B}$ activity in models of basal-like, claudin-low, and luminal A breast cancer; and (c) ENL inhibits viability and survival via modulation of NF- $\mathrm{KB}$ activity in the E0771 basal-like breast cancer model, the same model in which SDG inhibited in vivo tumor growth. To our knowledge, this is the first study to identify reduced NF- $\mathrm{KB}$ activity as a mediator of ENL's anti-tumor effects.

$\mathrm{NF}-\mathrm{\kappa B}$ is a transcription factor that is activated by numerous stimuli, such as growth factors and pro-inflammatory cytokines and chemokines. Its activation increases the expression of genes associated with tumor progression, including genes that promote resistance to apoptotic signals, cell proliferation and survival, angiogenesis, metastasis, and inflammation [36]. Elevated NF- $\mathrm{\kappa B}$ activity has been found in many cancers [37] and is particularly high in ER $\alpha$-negative breast cancer [38-40]. Using various breast cancer models, researchers have previously demonstrated a downregulation in NF- $\kappa \mathrm{B}$ activity following treatment with other phytoestrogens, including genistein, daidzein, and quercetin [41-43]. In the current study, we demonstrated a significant decrease in phosphorylated (Ser276) p65, an NF- $\kappa B$ family member, as well as NF- $\mathrm{\kappa B}$ target gene expression in the tumors of SDG-supplemented mice. No NF- $\kappa B$ target genes were significantly increased in the SDG-fed mice. This is consistent with a reduction in p-p65 (Ser276), as this phosphorylation increases p65 transcriptional activity [44]. Others have shown that reduced mammary stroma IL- $1 \beta$ production and increased mammary tumor IL-1Ra levels play roles in ENL's antiangiogenic effects [10], suggesting that ENL has additional anti-inflammatory effects that contribute to its antitumor activity. Furthermore, Jaskulski et al. [45] recently reported that the inverse association between serum ENL and breast cancer-specific mortality is partially mediated by $\mathrm{C}$-reactive protein, providing additional support for the hypothesis that ENL has anti-inflammatory activity. We found that constitutive Rela overexpression significantly 

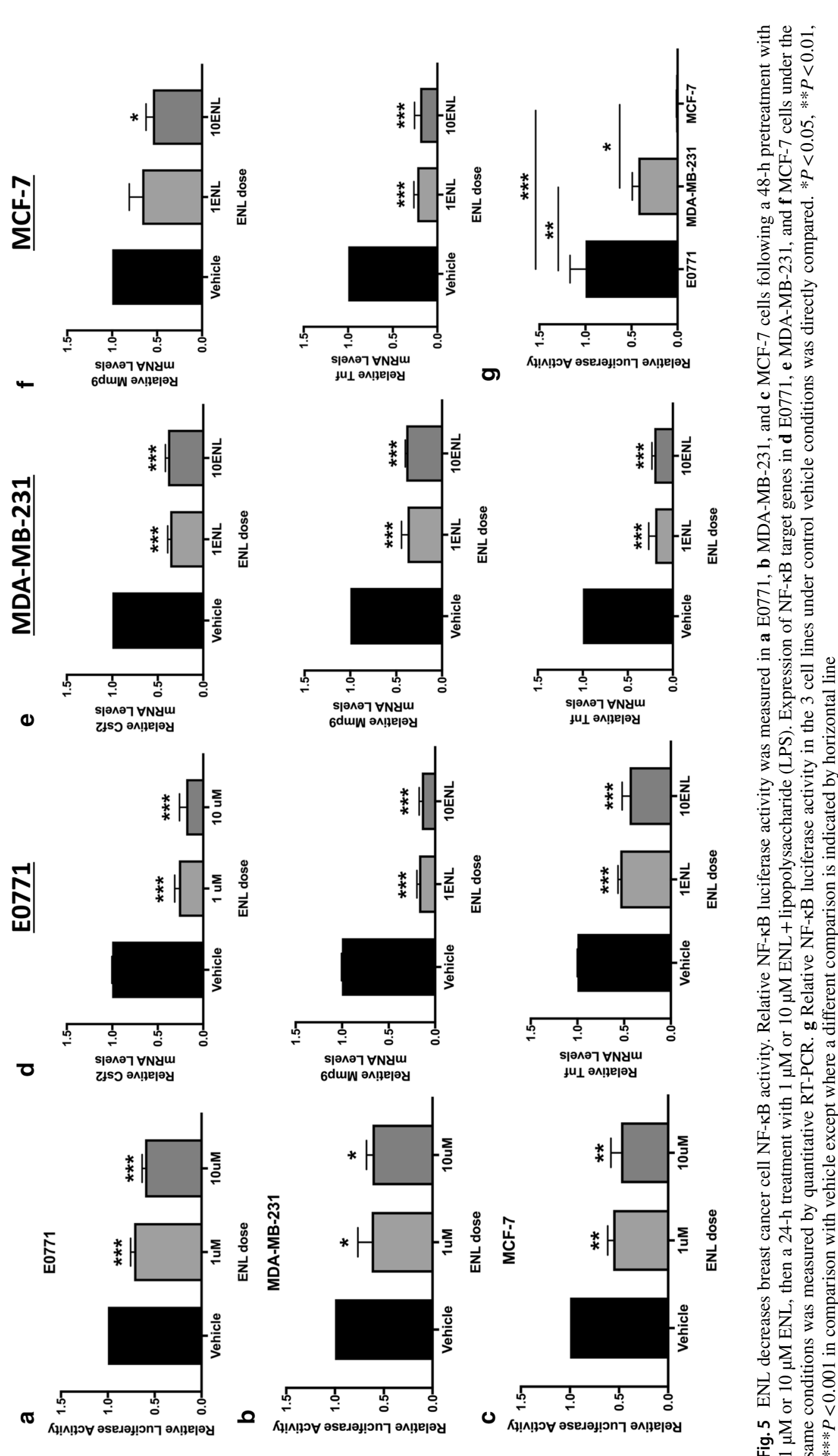

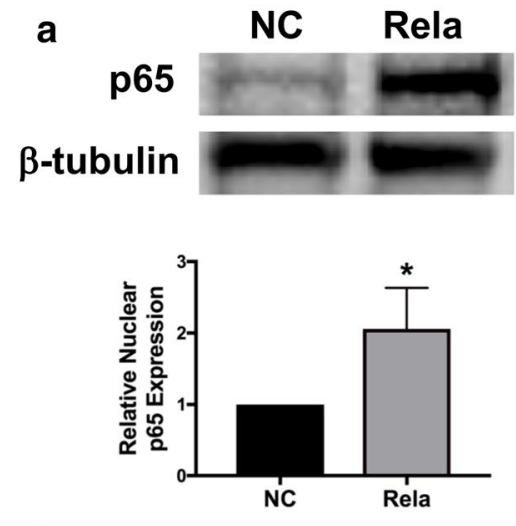

b

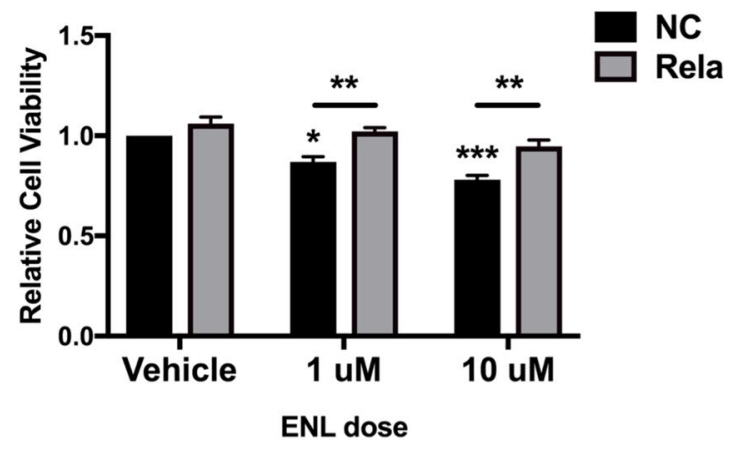

Fig. 6 ENL decreases E0771 cell viability and survival via inhibition of NF- $\kappa \mathrm{B}$ activity. a Nuclear p65 expression in E0771 cells transfected with a negative control vector (NC) or a Rela overexpression plasmid (Rela) was measured by western blot analysis. b Cell viability was measured by MTT assay in NC- and Rela-transfected E0771 cells following a 48-h treatment with $1 \mu \mathrm{M}$ or $10 \mu \mathrm{M}$ ENL. c Colony

attenuated ENL's inhibitory effects on viability and survival in the E0771 cell line, a model of basal-like breast cancer that is considered functionally triple-negative [21, $26,46,47]$, indicating that decreased activation of the $\mathrm{p} 65$ subunit of NF- $\kappa \mathrm{B}$ is a key mediator of ENL's effects in these cells. Given that SDG supplementation in the in vivo tumor study significantly decreased E0771 tumor growth and expression of several pro-proliferative and anti-apoptotic NF-кB target genes, including Bcl2ala, Birc2, Birc3, $E g f r 2$, and Xiap, we were surprised to find that the $10 \mu \mathrm{M}$ ENL treatment in vitro inhibited E0771 cell viability by only $27 \%$. This small effect size may be due to the limitations of our cell culture model, which only captured the direct effects of ENL exposure on the cancer cells and did not consider the possible role of other cell types in the tumor microenvironment. However, the same $10 \mu \mathrm{M}$ ENL treatment reduced E0771 colony formation by $65 \%$, suggesting that ENL does have a direct, biologically relevant impact on E0771 cell survival.

We also demonstrated that ENL reduces cell viability, survival, and NF- $\mathrm{BB}$ activity in MDA-MB-231 and MCF-7 cells, models of triple-negative claudin-low and
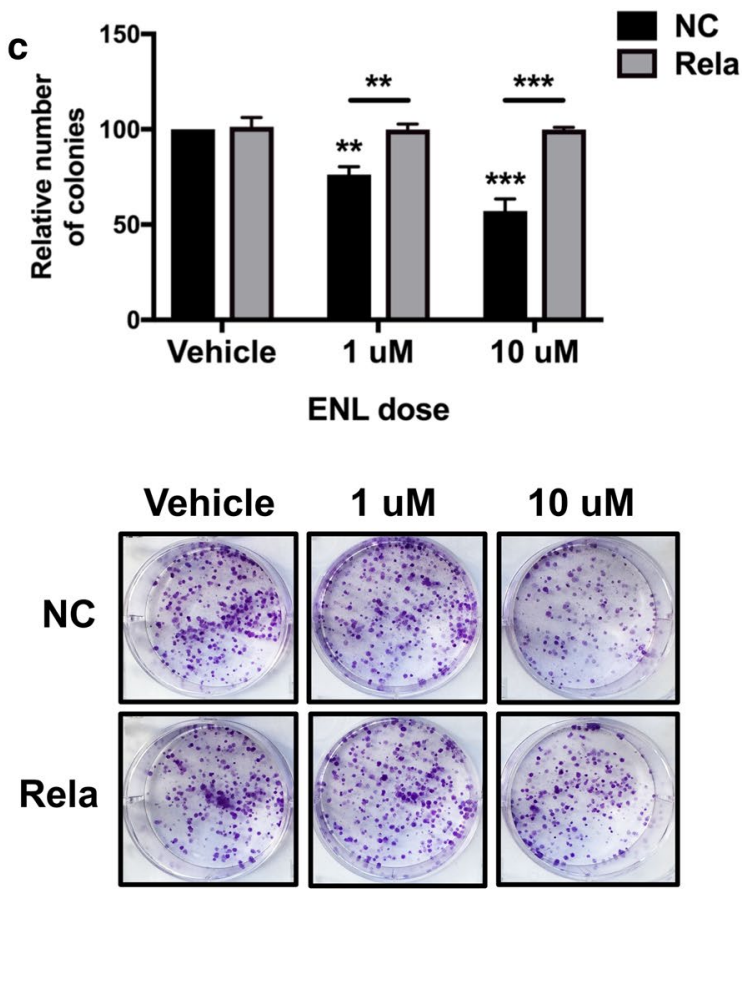

formation was quantified in NC- and Rela-transfected E0771 cells following a 7-day treatment with $1 \mu \mathrm{M}$ or $10 \mu \mathrm{M}$ ENL. Representative images were captured by a digital camera. $* P<0.05$; $* * P<0.01$, $* * * P<0.001$ in comparison with vehicle except where a different comparison is indicated by horizontal line

ER $\alpha$-positive luminal A breast cancer, respectively. Intriguingly, ENL treatment produced a twofold greater inhibition of viability in these 2 cell lines in comparison with the E0771 cells. However, there were no clear differences between the cell lines in inhibition of cell survival or NF- $\mathrm{\kappa B}$ activity, so the reason for the difference in viability remains unclear. We also observed that NF- $\mathrm{kB}$ activity in the MCF-7 cell line was significantly lower in comparison with the E0771 and MDA-MB-231 cells under vehicle conditions, and $1 / 2$ of the NF- $\kappa B$ target genes assessed were undetectable in this cell line. Consequently, the reduction in NF- $\mathrm{KB}$ activity observed in the MCF-7 cell line may not be biologically relevant, and ENL may act to reduce viability and survival in this cell line via an alternate mechanism. Our findings thus suggest that while ENL inhibits cell viability and survival across multiple breast cancer subtypes, biologically relevant ENL-induced inhibition of NF- $\mathrm{\kappa B}$ activity may be limited to nonluminal breast cancers, perhaps specifically to the basal-like and claudin-low subtypes.

A small number of prior studies have investigated SDG's effects in TNBC models. Treatment with ENL and END in vitro has been shown to reduce MDA-MB-231 cell 
proliferation, adhesion, migration, and invasion [22, 23]. Researchers have also demonstrated that ENL is a radiosensitizer [24] and enhances the cytotoxicity of chemotherapeutic agents [25] in MDA-MB-231 cells. In addition, supplementation with flaxseed oil or SDG in vivo was shown to inhibit metastasis from ER $\alpha$-negative MDA-MB-435 xenografts $[48,49]$. However, MDA-MB-435 cells are now known to be a melanoma cell line based on gene expression profiling and other analyses, so findings from studies utilizing MDA-MB-435 cells should be interpreted with caution.

Our current study examined the impact of ENL on cell lines representing multiple breast cancer subtypes, allowing us to delineate differences between the subtypes. However, there were several limitations to our studies. First, the in vivo studies did not use blinded outcome assessment, which can protect against potential bias in measurements and data reporting. In addition, the in vitro experiments that utilized the Rela overexpression plasmid to mechanistically link modulation of NF- $\mathrm{\kappa B}$ activity to ENL's anticancer effects were only performed in the E0771 cell line. Consequently, while MDA-MB-231 cells also responded to ENL with a decrease in NF- $\kappa$ B activity, we cannot conclude that this decrease is the cause of ENL's effects on cell viability and survival in this cell line. We also cannot generalize our findings regarding ENL's effects on the MCF-7 cell line to all ER $\alpha$-positive breast cancer. Given that this study aimed to focus on ER $\alpha$-negative disease, further exploration of ENL's effects on ER $\alpha$-positive cell lines was beyond its scope. Finally, our cell culture experiments did not include examination of the effects of END, the second SDG metabolite. We limited our in vitro investigation to ENL because it is considered the primary SDG enterolignan.

Our in vitro model was also limited by its focus on the direct effects of ENL on cancer cells, without an assessment of how ENL may be affecting the other cell types found in the tumor microenvironment, including macrophages. In the in vivo tumor study, we found a significant decrease in markers of macrophage infiltration in the normal mammary gland of SDG-supplemented mice. Given that inflammation within the tissue microenvironment has been clearly linked to the risk and progression of many types of cancer [50], this decrease in macrophage infiltration may play a role in SDG's anti-tumor effects. However, we did not explore this factor in our in vitro model, and it should thus be addressed in future studies. We also found that mice fed the SDG diet had lower tumor expression of Adgrel, the gene for the macrophage marker $\mathrm{F} 4 / 80$, but $\mathrm{F} 4 / 80$ protein expression was not significantly reduced in the SDG-supplemented mice. Consequently, we cannot conclude that tumor macrophage infiltration is affected by SDG in this model.

In summary, we have demonstrated that SDG reduces tumor growth in the E0771 model of basal-like breast cancer, likely via a mechanism involving inhibition of NF-KB activity. SDG has a highly favorable safety profile [27], and there is substantial evidence from population studies linking greater lignan exposure to reduced breast cancer mortality, including for ER $\alpha$-negative disease [4-8, 51, 52]. Consequently, SDG could serve as a practical and effective adjuvant treatment for the prevention of recurrence.

Acknowledgements The authors would like to thank the Setchell laboratory for their assistance in the measurement of SDG's metabolites. This study was supported by a Susan G. Komen Promise Grant (KG101039 to CJF and SDH), an investigator grant from the Breast Cancer Research Foundation (BCRF 16-075 to SDH), and an Outstanding Investigator Award from the National Cancer Institute (R35CA197627 to SDH). LWB and ELR were supported by fellowships from the National Cancer Institute (R25 CA057726).

Availability of data and material The datasets used and/or analyzed during the current study are available from the corresponding author on reasonable request.

\section{Compliance with ethical standards}

Conflict of interest The authors declare that they have no conflict of interest.

Ethical approval Animal studies and procedures were approved and monitored by the University of Texas Institutional Animal Care and Use Committee (AUP-2011-00005) and the University of North Carolina Institutional Animal Care and Use Committee (15-130.0-A). All experiments were conducted in a manner that complies with current U.S.A. law.

Open Access This article is distributed under the terms of the Creative Commons Attribution 4.0 International License (http://creativeco mmons.org/licenses/by/4.0/), which permits unrestricted use, distribution, and reproduction in any medium, provided you give appropriate credit to the original author(s) and the source, provide a link to the Creative Commons license, and indicate if changes were made.

\section{References}

1. Mazur W (1998) Phytoestrogen content in foods. Baillieres Clin Endocrinol Metab 12:729-742

2. Mazur WM, Wahala K, Rasku S, Salakka A, Hase T, Adlercreutz $\mathrm{H}$ (1998) Lignan and isoflavonoid concentrations in tea and coffee. Br J Nutr 79:37-45

3. Borriello SP, Setchell KD, Axelson M, Lawson AM (1985) Production and metabolism of lignans by the human faecal flora. $\mathrm{J}$ Appl Bacteriol 58:37-43

4. Buck K, Vrieling A, Zaineddin AK, Becker S, Husing A, Kaaks R, Linseisen J, Flesch-Janys D, Chang-Claude J (2011) Serum enterolactone and prognosis of postmenopausal breast cancer. $\mathrm{J}$ Clin Oncol 29:3730-3738

5. Buck K, Zaineddin AK, Vrieling A, Heinz J, Linseisen J, FleschJanys D, Chang-Claude J (2011) Estimated enterolignans, lignanrich foods, and fibre in relation to survival after postmenopausal breast cancer. Br J Cancer 105:1151-1157

6. Olsen A, Christensen J, Knudsen KE, Johnsen NF, Overvad K, Tjonneland A (2011) Prediagnostic plasma enterolactone levels 
and mortality among women with breast cancer. Breast Cancer Res Treat 128:883-889

7. Guglielmini P, Rubagotti A, Boccardo F (2012) Serum enterolactone levels and mortality outcome in women with early breast cancer: a retrospective cohort study. Breast Cancer Res Treat 132:661-668

8. Seibold P, Vrieling A, Johnson TS, Buck K, Behrens S, Kaaks R, Linseisen J, Obi N, Heinz J, Flesch-Janys D, Chang-Claude J (2014) Enterolactone concentrations and prognosis after postmenopausal breast cancer: assessment of effect modification and meta-analysis. Int J Cancer 135:923-933

9. Mabrok HB, Klopfleisch R, Ghanem KZ, Clavel T, Blaut M, Loh G (2012) Lignan transformation by gut bacteria lowers tumor burden in a gnotobiotic rat model of breast cancer. Carcinogenesis 33:203-208

10. Lindahl G, Saarinen N, Abrahamsson A, Dabrosin C (2011) Tamoxifen, flaxseed, and the lignan enterolactone increase stroma- and cancer cell-derived IL-1Ra and decrease tumor angiogenesis in estrogen-dependent breast cancer. Cancer Res 71:51-60

11. Saarinen NM, Abrahamsson A, Dabrosin C (2010) Estrogeninduced angiogenic factors derived from stromal and cancer cells are differently regulated by enterolactone and genistein in human breast cancer in vivo. Int J Cancer 127:737-745

12. Saarinen NM, Huovinen R, Warri A, Makela SI, ValentinBlasini L, Sjoholm R, Ammala J, Lehtila R, Eckerman C, Collan YU, Santti RS (2002) Enterolactone inhibits the growth of 7,12-dimethylbenz(a)anthracene-induced mammary carcinomas in the rat. Mol Cancer Ther 1:869-876

13. Bergman Jungestrom M, Thompson LU, Dabrosin C (2007) Flaxseed and its lignans inhibit estradiol-induced growth, angiogenesis, and secretion of vascular endothelial growth factor in human breast cancer xenografts in vivo. Clin Cancer Res 13:1061-1067

14. Thompson LU, Seidl MM, Rickard SE, Orcheson LJ, Fong HH (1996) Antitumorigenic effect of a mammalian lignan precursor from flaxseed. Nutr Cancer 26:159-165

15. Power KA, Saarinen NM, Chen JM, Thompson LU (2006) Mammalian lignans enterolactone and enterodiol, alone and in combination with the isoflavone genistein, do not promote the growth of MCF-7 xenografts in ovariectomized athymic nude mice. Int $\mathbf{J}$ Cancer 118:1316-1320

16. Chen J, Saggar JK, Corey P, Thompson LU (2009) Flaxseed and pure secoisolariciresinol diglucoside, but not flaxseed hull, reduce human breast tumor growth (MCF-7) in athymic mice. J Nutr 139:2061-2066

17. Saggar JK, Chen J, Corey P, Thompson LU (2010) Dietary flaxseed lignan or oil combined with tamoxifen treatment affects MCF-7 tumor growth through estrogen receptor- and growth factor-signaling pathways. Mol Nutr Food Res 54:415-425

18. Delman DM, Fabian CJ, Kimler BF, Yeh H, Petroff BK (2015) Effects of flaxseed lignan secoisolariciresinol diglucosideon preneoplastic biomarkers of cancer progression in a model of simultaneous breast and ovarian cancer development. Nutr Cancer 67:857-864

19. Mali AV, Joshi AA, Hegde MV, Kadam Sh S (2017) Enterolactone suppresses proliferation, migration and metastasis of MDAMB-231 breast cancer cells through inhibition of uPA induced plasmin activation and MMPs-mediated ECM remodeling. Asian Pac J Cancer Prev 18:905-915

20. Xiong XY, Hu XJ, Li Y, Liu CM (2015) Inhibitory effects of enterolactone on growth and metastasis in human breast cancer. Nutr Cancer 67:1324-1332

21. Johnstone CN, Smith YE, Cao Y, Burrows AD, Cross RS, Ling X, Redvers RP, Doherty JP, Eckhardt BL, Natoli AL, Restall CM, Lucas E, Pearson HB, Deb S, Britt KL, Rizzitelli A, Li J, Harmey JH, Pouliot N, Anderson RL (2015) Functional and molecular characterisation of EO771.LMB tumours, a new C57BL/6-mousederived model of spontaneously metastatic mammary cancer. Dis Model Mech 8:237-251

22. Chen J, Thompson LU (2003) Lignans and tamoxifen, alone or in combination, reduce human breast cancer cell adhesion, invasion and migration in vitro. Breast Cancer Res Treat 80:163-170

23. Mali AV, Wagh UV, Hegde MV, Chandorkar SS, Surve SV, Patole MV (2012) In vitro anti-metastatic activity of enterolactone, a mammalian lignan derived from flax lignan, and down-regulation of matrix metalloproteinases in MCF-7 and MDA MB 231 cell lines. Indian J Cancer 49:181-187

24. Bigdeli B, Goliaei B, Masoudi-Khoram N, Jooyan N, Nikoofar A, Rouhani M, Haghparast A, Mamashli F (2016) Enterolactone: A novel radiosensitizer for human breast cancer cell lines through impaired DNA repair and increased apoptosis. Toxicol Appl Pharmacol 313:180-194

25. Di Y, De Silva F, Krol ES, Alcorn J (2018) Flaxseed lignans enhance the cytotoxicity of chemotherapeutic agents against breast cancer cell lines MDA-MB-231 and SKBR3. Nutr Cancer 70:306-315

26. Yang Y, Yang HH, Hu Y, Watson PH, Liu H, Geiger TR, Anver MR, Haines DC, Martin P, Green JE, Lee MP, Hunter KW, Wakefield LM (2017) Immunocompetent mouse allograft models for development of therapies to target breast cancer metastasis. Oncotarget 8:30621-30643

27. Fabian CJ, Kimler BF, Zalles CM, Klemp JR, Petroff BK, Khan QJ, Sharma P, Setchell KD, Zhao X, Phillips TA, Metheny T, Hughes JR, Yeh HW, Johnson KA (2010) Reduction in Ki-67 in benign breast tissue of high-risk women with the lignan secoisolariciresinol diglycoside. Cancer Prev Res (Phila) 3:1342-1350

28. Setchell KD, Brown NM, Zimmer-Nechemias L, Wolfe B, Jha P, Heubi JE (2014) Metabolism of secoisolariciresinol-diglycoside the dietary precursor to the intestinally derived lignan enterolactone in humans. Food Funct 5:491-501

29. Rossi EL, Dunlap SM, Bowers LW, Khatib SA, Doerstling SS, Smith LA, Ford NA, Holley D, Brown PH, Estecio MR, Kusewitt DF, deGraffenried LA, Bultman SJ, Hursting SD (2017) Energy balance modulation impacts epigenetic reprogramming, ER $\alpha$ and ER $\beta$ expression, and mammary tumor development in MMTV-neu transgenic mice. Cancer Res 77:2500-2511

30. Dunlap SM, Chiao LJ, Nogueira L, Usary J, Perou CM, Varticovski L, Hursting SD (2012) Dietary energy balance modulates epithelial-to-mesenchymal transition and tumor progression in murine claudin-low and basal-like mammary tumor models. Cancer Prev Res (Phila) 5:930-942

31. Mueller SO, Simon S, Chae K, Metzler M, Korach KS (2004) Phytoestrogens and their human metabolites show distinct agonistic and antagonistic properties on estrogen receptor alpha (ERalpha) and ERbeta in human cells. Toxicol Sci 80:14-25

32. Carreau C, Flouriot G, Bennetau-Pelissero C, Potier M (2008) Enterodiol and enterolactone, two major diet-derived polyphenol metabolites have different impact on ERalpha transcriptional activation in human breast cancer cells. J Steroid Biochem Mol Biol 110:176-185

33. Bowers LW, Cavazos DA, Maximo IX, Brenner AJ, Hursting SD, deGraffenried LA (2013) Obesity enhances nongenomic estrogen receptor crosstalk with the PI3K/Akt and MAPK pathways to promote in vitro measures of breast cancer progression. Breast Cancer Res 15:R59

34. Bowers LW, Rossi EL, McDonell SB, Doerstling SS, Khatib SA, Lineberger CG, Albright JE, Tang X, deGraffenried LA, Hursting SD (2018) Leptin signaling mediates obesity-associated CSC enrichment and EMT in preclinical TNBC models. Mol Cancer Res 16:869-879 
35. Rickard SE, Yuan YV, Chen J, Thompson LU (1999) Dose effects of flaxseed and its lignan on N-methyl-N-nitrosourea-induced mammary tumorigenesis in rats. Nutr Cancer 35:50-57

36. Harvey AE, Lashinger LM, Hursting SD (2011) The growing challenge of obesity and cancer: an inflammatory issue. Ann N Y Acad Sci 1229:45-52

37. Rayet B, Gelinas C (1999) Aberrant rel/nfkb genes and activity in human cancer. Oncogene 18:6938-6947

38. Sovak MA, Bellas RE, Kim DW, Zanieski GJ, Rogers AE, Traish AM, Sonenshein GE (1997) Aberrant nuclear factor-kappaB/Rel expression and the pathogenesis of breast cancer. J Clin Invest 100:2952-2960

39. Nakshatri H, Bhat-Nakshatri P, Martin DA, Goulet RJ Jr, Sledge GW Jr (1997) Constitutive activation of NF-kappaB during progression of breast cancer to hormone-independent growth. Mol Cell Biol 17:3629-3639

40. Biswas DK, Cruz AP, Gansberger E, Pardee AB (2000) Epidermal growth factor-induced nuclear factor kappa B activation: a major pathway of cell-cycle progression in estrogen-receptor negative breast cancer cells. Proc Natl Acad Sci USA 97:8542-8547

41. Seo HS, Choi HS, Choi HS, Choi YK, Um JY, Choi I, Shin YC, Ko SG (2011) Phytoestrogens induce apoptosis via extrinsic pathway, inhibiting nuclear factor-kappaB signaling in HER2overexpressing breast cancer cells. Anticancer Res 31:3301-3313

42. Valachovicova T, Slivova V, Bergman H, Shuherk J, Sliva D (2004) Soy isoflavones suppress invasiveness of breast cancer cells by the inhibition of NF-kappaB/AP-1-dependent and -independent pathways. Int J Oncol 25:1389-1395

43. Banerjee S, Li Y, Wang Z, Sarkar FH (2008) Multi-targeted therapy of cancer by genistein. Cancer Lett 269:226-242

44. Christian F, Smith EL, Carmody RJ (2016) The regulation of NFkappaB subunits by phosphorylation. Cells 5
45. Jaskulski S, Jung AY, Behrens S, Johnson T, Kaaks R, Thone K, Flesch-Janys D, Sookthai D, Chang-Claude J (2018) Circulating enterolactone concentrations and prognosis of postmenopausal breast cancer: assessment of mediation by inflammatory markers. Int J Cancer

46. Gu JW, Young E, Patterson SG, Makey KL, Wells J, Huang M, Tucker KB, Miele L (2011) Postmenopausal obesity promotes tumor angiogenesis and breast cancer progression in mice. Cancer Biol Ther 11:910-917

47. Ke JY, Banh T, Hsiao YH, Cole RM, Straka SR, Yee LD, Belury MA (2017) Citrus flavonoid naringenin reduces mammary tumor cell viability, adipose mass, and adipose inflammation in obese ovariectomized mice. Mol Nutr Food Res 61

48. Wang L, Chen J, Thompson LU (2005) The inhibitory effect of flaxseed on the growth and metastasis of estrogen receptor negative human breast cancer xenograftsis attributed to both its lignan and oil components. Int J Cancer 116:793-798

49. Chen J, Wang L, Thompson LU (2006) Flaxseed and its components reduce metastasis after surgical excision of solid human breast tumor in nude mice. Cancer Lett 234:168-175

50. Colotta F, Allavena P, Sica A, Garlanda C, Mantovani A (2009) Cancer-related inflammation, the seventh hallmark of cancer: links to genetic instability. Carcinogenesis 30:1073-1081

51. Buck K, Zaineddin AK, Vrieling A, Linseisen J, Chang-Claude J (2010) Meta-analyses of lignans and enterolignans in relation to breast cancer risk. Am J Clin Nutr 92:141-153

52. Zaineddin AK, Vrieling A, Buck K, Becker S, Linseisen J, FleschJanys D, Kaaks R, Chang-Claude J (2012) Serum enterolactone and postmenopausal breast cancer risk by estrogen, progesterone and herceptin 2 receptor status. Int J Cancer 130:1401-1410 